\title{
The pandemic of 2019 novel coronavirus infection and Hajj
}

\section{1}

\section{Behroz Mahdavi Poor ${ }^{1}$, Jalil Rashedi ${ }^{*}$, Nazila Gheitarani² and Mohammad Asgharzadeh ${ }^{3}$}

'Department of Laboratory Sciences, Faculty of Para Medicine, Tabriz University of Medical Sciences, Tabriz, Iran

${ }^{2}$ Department of Population and Family Health, Vice Chancellor for Health, Tabriz University of Medical Sciences, Tabriz, Iran

${ }^{3}$ Biotechnology Research Center, Tabriz University of Medical Sciences, Tabriz, Iran
Received: 21 December, 2020

Accepted: 29 December, 2020

Published: 30 December, 2020

*Corresponding author: Jalil Rashedi, Faculty of Para Medicine, Tabriz University of Medical Sciences, Golgasht Ave, Azadi St, Tabriz, I.R. Iran, Tel: +984133392633, +989149167845; Fax: +9841-33371971; E-mail: Rashedijalil@gmail.com

https://www.peertechz.com

Check for updates

\section{Dear Editor-in-Chief}

In December 2019, an outbreak of severe pneumonia of anonymous etiology was reported from Wuhan city, China. The Chinese health authorities rapidly determined the causative agent of the disease as a novel coronavirus (2019-nCoV) [1]. Coronavirus Disease 2019 (COVID-19) quickly widespread and becomes a major public health concern throughout the world. Growing evidences, including transmission of the infection among family members and infection of the hospital workers revealed the ability of the emerging virus to transmit continuously from human-to-human $[1,2]$. Common findings in symptomatic cases are fever, dry cough, dyspnoea, and view of bilateral regions of ground-glass opacities on chest CT scans with a mortality rate of approximately $2 \%$. [3,4]. Until now, no approved therapeutic agent and vaccine is available for the treatment of human coronavirus infections [4].

The incubation period of COVID-19 has been estimated from 2 to 11 days (the mean period of 6.4 days). The basic reproduction number $\left(R_{0}\right)$ has also been calculated of approximately 2.2 which means that each patient transmits the infection to 2.2 other individuals. The finding indicates the high transmissibility nature of the virus and its potential for causing outbreaks [5]. COVID-19 become more severe among the elderly or people with underlying diseases such as cardiovascular disease, hypertension, diabetes mellitus and can even lead to death $[3,6]$. Therefore, strict adherence to preventive measures is necessary to reduce the burden of the disease. Participation in all mass gatherings, including religious festivals should be limited, especially in the elderly or those with the underlying disease.

The Hajj, the annual pilgrimage to Makkah, Saudi Arabia, is one of the greatest religious gatherings throughout the world, attracting more than two million pilgrims from more than 184 countries [7]. Participation in Hajj is obligatory at least once in a lifetime for adult Muslims who has the physical and financial ability [8]. One of the significant public health issues in relation to the pilgrimage is the risk of infectious pathogens importation to the host country or transmission of the acquired pathogens by pilgrims to their country of origin. During Hajj, pilgrims are accommodated in crowded places and involve in various gatherings, which exposes them to respiratory infectious diseases [7]. The current pandemic of COVID-19 is a major public health challenge for the implementation and management of the Hajj 2021. Protecting the health of pilgrims and residents of Saudi Arabia and subsequently the maintenance of the Middle East and global health security should be a main priority of the Hajj administration system. It is recommended that pilgrims receive the additional public health education to prevent the transmission of respiratory infections, especially COVID-19, prior to the event. Providing packages containing personal protective equipment such as disinfectant sprays, gloves, N95 masks, and safety glasses to all pilgrims can help prevent the disease transmission. It is also recommended to postpone Hajj 2021 of elderly pilgrims and those with underlying disease. 


\section{References}

1. Riou J, Althaus $\mathrm{CL}$ (2020) Pattern of early human-to-human transmission of Wuhan 2019 novel coronavirus (2019-nCoV). Euro Surveill 25: 2000058. Link: https://bit.ly/2KMisNU

2. Xu Y (2020) Unveiling the Origin and Transmission of 2019-nCoV. Trends Microbiol 28: 239-240. Link: https://bit.ly/37VNcF1

3. Huang C, Wang Y, Li X, Ren L, Zhao J, et al. (2020) Clinical features of patients infected with 2019 novel coronavirus in Wuhan, China. Lancet 395: 497-506. Link: https://bit.ly/2MhDXqv

4. Li G, De Clercq E (2020) Therapeutic options for the 2019 novel coronavirus (2019-nCoV). Nat Rev Drug Discov 19: 149-150. Link: https://bit.ly/2McglOp
5. Li Q, Guan X, Wu P, Wang X, Zhou L, et al. (2020) Early Transmission Dynamics in Wuhan, China, of Novel Coronavirus-Infected Pneumonia. N Engl J Med 382 1199-1207. Link: https://bit.ly/2WUw4Jr

6. Lai CC, Shih TP, Ko WC, Tang HJ, Hsueh PR (2020) Severe acute respiratory syndrome coronavirus 2 (SARS-CoV-2) and coronavirus disease-2019 (COVID-19): The epidemic and the challenges. Int J Antimicrob Agents 55: 105924. Link: https://bit.ly/2JvEsMC

7. Memish ZA, Zumla A, Alhakeem RF, Assiri A, Turkestani A, et al. (2014) Haj: infectious disease surveillance and control. Lancet 383: 2073-2082. Link: https://bit.ly/38D5vOw

8. Benkouiten S, Al-Tawfiq JA, Memish ZA, Albarrak A, Gautret P (2019) Clinical respiratory infections and pneumonia during the Hajj pilgrimage: A systematic review. Travel Med Infect Dis 28: 15-26. Link: https://bit.ly/2L7oPeQ

\section{Discover a bigger Impact and Visibility of your article publication with} Peertechz Publications

\section{Highlights}

* Signatory publisher of ORCID

- Signatory Publisher of DORA (San Francisco Declaration on Research Assessment)

* Articles archived in worlds' renowned service providers such as Portico, CNKI, AGRIS, TDNet, Base (Bielefeld University Library), CrossRef, Scilit, J-Gate etc.

* Journals indexed in ICMJE, SHERPA/ROMEO, Google Scholar etc.

* OAI-PMH (Open Archives Initiative Protocol for Metadata Harvesting)

* Dedicated Editorial Board for every journa

* Accurate and rapid peer-review process

* Increased citations of published articles through promotions

* Reduced timeline for article publication

Submit your articles and experience a new surge in publication services (https://www.peertechz.com/submission).

Peertechz journals wishes everlasting success in your every endeavours.

Copyright: @ 2020 Poor BM, et al. This is an open-access article distributed under the terms of the Creative Commons Attribution License, which permits unrestricted use, distribution, and reproduction in any medium, provided the original author and source are credited

Citation: Poor BM, Rashedi J, Gheitarani N, Asgharzadeh M (2020) The pandemic of 2019 novel coronavirus infection and Hajj 2021. Arch Prev Med 5(1): 070-071. DOI: https://dx.doi.org/10.17352/apm.000024 